\title{
The Effects of Using Snake and Ladder Media towards Elementary School Students' Learning Outcomes
}

\author{
Yuli Mulyawati ${ }^{1 *}$, Tustiyana Windiyani ${ }^{1}$ \\ ${ }^{1}$ Department of Elementary Education, Pakuan University, Bogor, Indonesia \\ *yuli mulyawati@unpak.ac.id
}

Revised: August $13^{\text {th }}, 2020$

Accepted: August $15^{\text {th }}, 2020$

\begin{abstract}
The purpose of this study was to determine the effect of using snake and ladder learning media towards students' learning outcomes. This study used an experimental research method with a one-group pretest-posttest design. The research was conducted 34 fourth grade students from SDN Katulampa 1 Bogor in odd semester of 2020/2021 academic year. The analysis technique used is the analysis prerequisite test which includes the normality and homogeneity test. The research hypothess is carried out using the t-test. The results of experiment 1 showed that the scores of students' learning outcomes increased from an average pretest score of 50.00 to 80.00 of posttests with N-Gain 60.00 . While, the experiment 2 with the effect of using snake and ladder learning media resulted in an average pretest score of 53.43, posttest of 85.29, and N-Gain 68. Based on the results of the research, it can be concluded that there is an effect of the use of snake and ladder learning media towards elementary school students' learning outcomes.
\end{abstract}

Keywords: learning media; students' learning outcomes; snake and ladder media.

\section{INTRODUCTION}

Education is very important in the development of a country. Education plays a role in increasing the capacity of human resources. For this reason, increasing education is very important, but currently, where Indonesia is being hit by the Covid-19 outbreak, education has decreased in scale so that certain efforts are needed from all parties to improve it. The most visible thing from the current state of the COVID-19 outbreak is that it requires students to school from home; this has caused a reaction to students in their learning. On the one hand, students are required to improve their abilities in the cognitive realm, and on the other hand, students are required to be able to follow developments employing distance/ online learning that utilize information technology. This situation has an impact on the readiness of students in learning at home.

The results of observations and interviews with students, teachers, and parents that were carried out through WhatsApp, obtained data that students were bored if they only studied material from the theme book, watched television 
or YouTube. Students feel that studying at home with the same media does not stimulate students to be actively involved in learning so that they become bored.

The online learning process should have interactions between teachers and students, so that students are actively involved in the learning process. Besides, the delivery of material with the lecture method that is delivered by the teacher in online learning is more in one direction only, there is no learning practice, this causes interest in learning to decrease.

Lack of interest in learning makes student learning outcomes less than the minimum completeness criteria. Based on the results of the pre-research on the theme "The beauty of togetherness", sub-theme 1 "Togetherness in Diversity", the results obtained from 34 grade 4 students of SDN Katulampa 1 who reached the minimum completeness criteria were only 21 people or $62 \%$ while 13 people or $38 \%$ had not reached the minimum completeness criteria.

The low learning outcomes of students in grade 4 SDN Katulampa 1 Bogor City are caused by several things including, (1) the material is difficult for students to understand because students have to memorize names and types of culture, (2) only use textbooks as a learning resource, (3) the learning media used are less varied, (4) lack of interest in students when learning takes place.

Efforts that can be made to increase student interest and learning outcomes at School From Home (SFH) include using interactive learning media through games. (Salam, Safei \& Jamilah, 2019)
Media that can be used in the game include Snakes and Ladders' learning media. This snake and ladder game media aims to increase student activity, enthusiasm for learning, and dare to express opinions that will have an impact on increasing student learning outcomes and can make it easier for teachers to deliver learning material (Dewi, Kurnia \& Panjaitan, 2017).

The use of instructional media in the delivery of learning materials is very necessary so that learning becomes more effective and efficient and enjoyable. This refers to the notion of learning media as everything both physical and technical in the learning process that can help teachers to make it easier to convey subject matter to students so that it makes it easier to achieve the learning objectives that have been formulated. (Adam, 2015)

Based on the identification of the problems above, the problem can be formulated as follows: Is there an effect of the use of snake and ladder learning media on student learning outcomes in elementary schools? "

This research must be conducted because if the students' interest in learning is low, it will have an impact on the learning situation and conditions so that it will affect student learning outcomes. This study also provides an alternative to teachers in teaching material at school using snake and ladder media, so that students will be more interested in learning. 


\section{THEORETICAL FRAMEWORK \\ a. Learning Media Definition of Learning Media}

The word media comes from Latin, medius which literacy means "middle", "intermediary" or "introduction". According to Gerlach and Ely (in Arsyad, 2017), media when understood in broad terms is human, material, or events that build conditions that enable students to acquire knowledge, skills, or attitudes. In this sense, the teacher, text, and the school environment are the media.

More specifically, the notion of media in the teaching and learning process tends to be interpreted as graphic, photographic, or electronic tools to capture, process, and reconstruct visual or verbal information.

According to Munadi (2020) Learning media is anything that can convey and channel messages from sources in a planned manner to create a conducive learning environment where the recipient can carry out the learning process efficiently and effectively. Furthermore, according to Musfiqon (2012) that learning media is defined as a physical or non-physical tool that is deliberately used as an intermediary between teachers and students in understanding learning material to make it more effective and efficient. So that the learning material is more fully accepted by students and attracts students' interest to study further.

Based on the description above, the authors conclude that the media is an intermediary or importer of subject matter to achieve learning objectives.
Learning media can also generate interest and student learning outcomes.

\section{Function of Media in Learning Process}

Learning media has several functions that support the teaching and learning process. According to Kemp and Dayton (Sundayana, 2016) that there are three main functions in the following instructional media : (1) To motivate interest or action, to fulfill a motivational function, teaching media can be realized with role-playing or entertainment techniques. (2) Presenting the information, content, form this presentation is very general, serves as an introduction, summary, or knowledge or motivation techniques. (3) Giving instructions, for instructions where the information contained in the media must involve students either in mind or mentally or in the form of real activities so that learning can occur.

Based on the description above, the function of learning media is to motivate interest or action, present information, content, general presentation forms, and provide instructions.

\section{Terms and Criteria of Learning Media}

The selection of instructional media to be used must be based on clear intent and selection. The selection of media must be following the terms and criteria for the learning media so that the learning media can be of good use and support the teaching and learning process. 
According to Raharjo (Mulyana, 2016) that the terms and criteria for learning media are as follows: (1) The purpose of the selection itself must be clear. (2) Familirialitas media, the media must recognize the nature and characteristics. (3) The selection should be based on certain criteria as standards and standards.

\section{b. Snake and Ladder Game}

The game of snakes and ladders is a game that is familiar to Indonesians. This game is a game that is widely liked. Snake and ladder games can be played by anyone and anywhere. This game is an interactive game. This was announced by (Haryono, 2013) that the game of snakes and ladders is a popular form of the game that is popular among children, adolescents, and even adults. In this game, players play against each step carefully prosecuted to quickly resolve the finish.

The snake and ladder game media is a two-dimensional visual media with the concept of the game of snakes and ladders in general, but there is an educational element in the game (Aniq, 2013) In general, the game of snakes and ladders is a board game for children played by 2 or more people. The game board is divided into small squares and in some squares, several ladders and snakes are drawn connecting them to other squares. As for the play snakes and ladders, some rules must be obeyed by every player.

Rules for the game of snakes and ladders on the theme of "The beauty of togetherness": (1) Decide who will play first. (2) Roll the dice and move. (3) Ascend while on the staircase. (4) Get down when stopping at the snake's square and take the card (answer the question). (5) if you get a 6 take an extra turn (6) To win the game, stop right on the last square.

The purpose of using snake and ladder media is to foster interest, motivation, and enthusiasm for student learning so that they are always enthusiastic about participating in learning activities. This goal is in line with the statement put forward by Ginsburg and Opper (Nursuprianah, 2015) young children will learn more easily from real (concrete) experiences and assignments will result in children always reading them, paying attention to them, and learning them.

From these statements, it is clear that the purpose of using game media is to motivate students to learn. When motivation increases, students will be more enthusiastic about learning.

\section{Advantages and Disadvantages of Snakes and Ladders}

Every media has its advantages and disadvantages. In general (Sadiman, 2012) Says the advantages of game media as follows: (1) Games are something that is fun to do and something entertaining. (2) Games allow the active participation of students in learning. (3) The game can provide immediate feedback. Prompt feedback on what we are doing will enable the learning process to be more effective. (4) 
The game is flexible because the game can be used for various purposes by changing a few tools, rules, and problems (modification). (5) Games can be easily created and reproduced. (6) Making a good game does not require someone skilled.

Disadvantages of Snakes and Ladders as follows : (1) Most games involve only a few students even though the involvement of all students is very important so that the learning process can be more effective and efficient. (2) Students who have not yet covered the rules/ technical implementation will obstruct the game.

\section{c. Learning Outcomes}

Learning outcomes is the attainment of a form of behaviour change that tends to persist from the cognitive, affective, and psychomotor domains of the learning process carried out within a certain time (Jihad, 2013).

Dimyati and Mudjiono (2015) reveal that the main goal of learning outcomes is to determine the level of success achieved by students after participating in a learning activity where the success rate is then marked by a value scale in the form of letters or words or symbols. achievement of learning outcomes in this study.

\section{METHODS}

This research was conducted in grade 4 SDN Katulampa 1 Kacamatan Bogor Timur, Bogor City, in the learning theme 1 "The beauty of togetherness" and the sub-theme "Togetherness in Diversity".

This research was conducted in July, Odd Semester, 2020/2021 academic year. The research design used is an experimental design that is preexperimental with a one-group pretestposttest design, in a study, there must be a research design because the research design will be a clearer handle in conducting research.

One-group pretest-posttest design in this design has a pretest, before being given treatment. Thus the results of the treatment can be found out more accurately because they can compare with the situation before being treated (Sugiyono, 2017)

The experimental research design of one group (class) was given the same treatment. Before being given the treatment, a pretest was carried out in the class to find out the extent of the basic abilities of students about the concept in question, then given treatment using the snake and ladder learning media, after that the Posttest was carried out again to find out the extent of student mastery of the concept in question after being given treatment.

The research design is presented in figure 1.

$\mathrm{O} 1 \longrightarrow \mathrm{X} \longrightarrow \mathrm{O} 2$

Figure 1 . The research design

(Sugiyono, 2017)
$\mathrm{O} 1=$ Pretest

$\mathrm{X}=$ Treatment

$\mathrm{O} 2=$ Posttest 


\section{a. Research Population}

In connection with the limited population of 34 people (one class) consisting of 16 men and 18 women, in this study, the researchers did not draw samples.

\section{b. Data Collection Techniques}

The data collection technique in this study was a test. The test is a set of tasks that must be done by students to measure the level of understanding and mastery of the required material coverage and following certain teaching objectives. The test is used before (pretest) and after (posttest) learning is carried out.

\section{RESULTS}

\section{a. Results of Experiment 1}

The research was carried out in Class 4 SDN Katulampa 1 Bogor City on Monday, July 20, 2020, odd semester of the 2020/2021 school year on Theme 1 "The Beauty of Togetherness" Sub Theme 2 "Togetherness in Diversity",
Learning 1 with learning content: Indonesian language, Citizenship Education, and Natural Sciences. Based on the results of research in experiment 1, the following data are obtained:

Based on the data obtained before students received treatment or learning using snake and ladder learning media, the lowest score was 40, and the highest score was 65 , while the average score was 50.

Based on the data obtained after students received treatment or learning using snake and ladder learning media, the lowest score was 65 , and the highest score was 90 , while the average score was 80.

Based on the data obtained before and after learning using snake and ladder learning media, then $\mathrm{N}$-Gain is calculated so that the lowest score is 25 and the highest score is 83 , while the average value is 60 .

The frequency distribution of the $\mathrm{N}$ Gain score for experiment 1 is presented in figure 2.

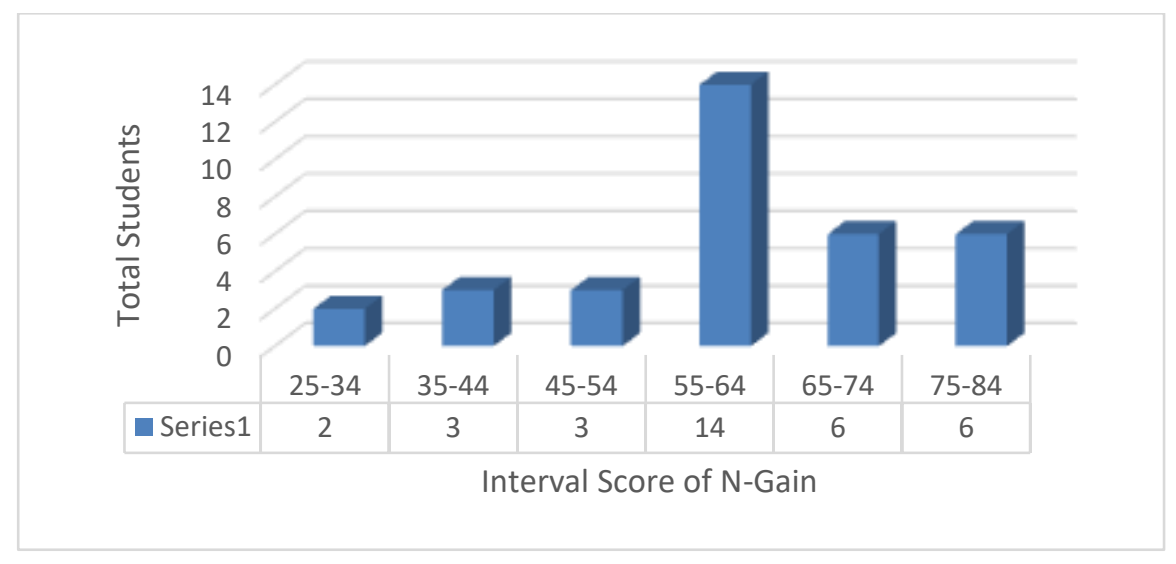

Figure 2. Recapitulation Score N-Gain Experiment 1 
Based on the histogram above, it was obtained that the $\mathrm{N}$-Gain score in the experimental class 1 had various $\mathrm{N}$-Gain scores. There are 2 students in the 25-34 score interval, 3 students in the 35-48 score interval, 3 students who are in the 45-54 score interval, 3 students who are in the 55-64 score interval as many as 14 people, 6 students who were in the score interval $65-74,6$ students who were in the 75-84 score interval.

\section{b. Results of Experiment 2}

The research was carried out in Class

4 SDN Katulampa 1 Bogor City on Thursday, July 23, 2020, odd semester of the 2020/2021 school year on Theme 1 "The Beauty of Togetherness" Sub Theme 2 "Togetherness in Diversity", Learning 4 with learning content: Indonesian language, Citizenship Education, and Social Sciences. Based on the results of research in experiment 2 , the following data are obtained:

Based on the data obtained before students get treatment or learning using snake and ladder learning media, the lowest score is 40 , and the highest score is 65 , while the average value is 53.43 .

Based on the data obtained after students received treatment or learning using snake and ladder learning media, the lowest score was 70, and the highest score was 95, while the average value was 85.29.

Based on the data obtained before and after learning using the Snake and Ladder Learning Media, then N-Gain is calculated so that the lowest score is 68 , and the highest score is 90 while the average score is 60 .

The frequency distribution of the $\mathrm{N}$ Gain score for experiment 2 is presented in figure 3.

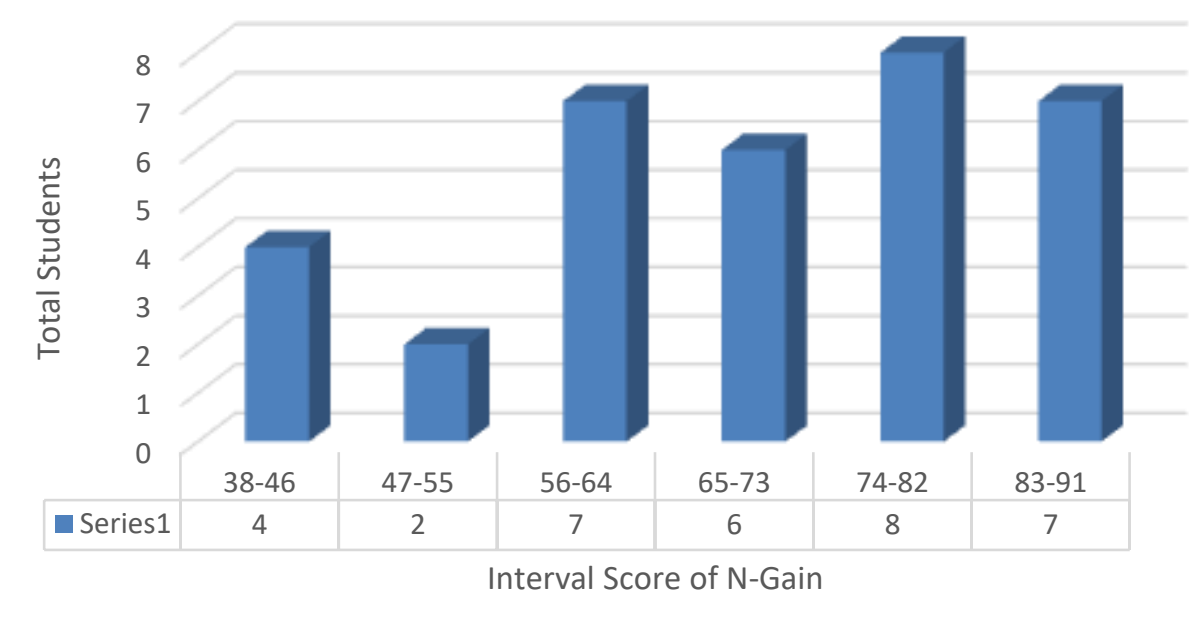

Figure 3. Recapitulation Score N-Gain Experiment 2 
Based on the frequency distribution table above, it was obtained that the $\mathrm{N}$ Gain score in experiment 2 using the snake and ladder learning media had various $\mathrm{N}$-Gain scores. There were 4 students in the 38-46 score interval, 2 students in the 47-55 score interval, 7 students in the 56-64 score interval, 6 students in the 65-73 score interval
There were 8 students in the 74-82 score interval, 7 students in the 83-91 score interval.

Based on the results of the implementation of experimental research 1 and experiment 2 the use of snake and ladder learning media can be summarized in table 1.

Table 1. Recapitulation Score N-Gain

\begin{tabular}{cccc}
\hline \multicolumn{2}{c}{ Recapitulation score } & Experiment 1 & Experiment 2 \\
\hline \multirow{4}{*}{ Lowest score } & Pretest & 40 & 40 \\
& Posttest & 65 & 70 \\
Highest score & N-Gain & 25 & 38 \\
& Pretest & 65 & 65 \\
& Posttest & 90 & 95 \\
Average score & N-Gain & 83 & 90 \\
& Pretest & 50 & 53.43 \\
& Posttest & 80 & 85.29 \\
& N-Gain & 60 & 68 \\
\hline
\end{tabular}

\section{DISCUSSION}

Based on the research results, the use of snake and ladder learning media in experiment 1 and experiment 2 affects student learning outcomes. This can be seen from the increase in student learning outcomes before (pretest) and after (posttest). Student learning outcomes can be seen in experiment 1 , the posttest results show the lowest score of 65 and the highest score of 90 and N-Gain 83 in the High category. Experiment 1 is considered insufficient to prove that there is an effect of using snake and ladder media on student learning outcomes, this is based on the results of observations and interviews with students, there are still some students who do not understand the concepts being taught, so when the snake and ladder game is carried out they feel confused when going to Answer the question. The use of snake and ladder media in learning is something new for grade 4 students of SDN Katulampa 1 so it takes longer to carry out this game. This affects student learning outcomes. In connection with this right, the use of snake and ladder media was continued in experiment 2 .

Based on the results of the study that the use of learning media for snakes and ladders in experiment 2, the lowest posttest score was 70 and the highest score was 95 and the N-Gain score was 90 in the High category. These results indicate that there is a change in the increase in learning outcomes in 
experiment 2. This is influenced by students getting more understanding of the concept, students getting more familiar with the rules of the game in the snake and ladder game, students are motivated to learn using the snake and ladder media. students are increasingly interested in learning.

\section{CONCLUSION}

This research can show that there is an influence of snake and ladder learning media on student learning outcomes in elementary schools. With the use of snake and ladder, media students can find new and interesting things that can make students active in the learning process both as a group and individually. The difference in student activity in the learning process makes students excited about learning. However, in experiment 1 students had difficulty remembering the diversity that exists in Indonesia. This is caused by certain factors such as the ability of the teacher/researcher to understand the material and use the media, conformity with teaching material, manage classes, time management, and so on.

\section{ACKNOWLEDGEMENT}

The authors thank the Ministry of Research, Technology, and Higher Education for funding this Research, and also thank the Headmaster of SDN Katulampa 1 Bogor for giving permission to conduct this study.

\section{REFERENCES}

Adam, S. (2015). Pemanfaatan Media
Pembelajaran Berbasis Teknologi Informasi Bagi Siswa Kelas X Sma Ananda Batam. CBIS Journal, 3 No 2(ISSN 2337-8794), 78-90.

Aniq, M. (2013). Meningkatkan Hasil Belajar Siswa Pada Pembelajaran Ips Dengan Menggunakan Model Pembelajaran Think Pair Share (Tps) Dan Media Gambar Di SD 06 Bulungcangkring Jekulo Kudus. Skripsi.

Arsyad, A. (2017). Media Pembelajaran (edisi revi). Rajawali Pers.

Dewi, T. L., Kurnia, D., \& Panjaitan, R. L. (2017). Penggunaan Media Permainan Ular Tangga Pada Pembelajaran PIPS Untuk Meningkatkan Hasil Belajar Siswa Pada Materi Pembagian Wilayah Waktu DI Indonesia. Jurnal Pena Ilmiah, 2(1), 2091-2100. https://doi.org/10.17509/jpi.v2i1.12 425

Dimyati, D., \& Mudjiono, M. (2015). Belajar dan Pembelajaran. Rineka Cipta.

Haryono. (2013). Pembelajaran IPA yang Menarik dan Mengasyikkan. Kepel Press.

Jihad, A. (2013). Evaluasi Pembelajaran. Multi Pressindo.

Mulyana, Y. (2016). Pengantar Pembelajaran Penjas. STKIP Sebelas April Press.

Munadi, Y. (2020). Media Pembelajaran. 


\section{Gaung Persada Press.}

Musfiqon. (2012). Pengembangan Media dan Sumber Pembelajaran. Prestasi Pustaka Raya.

Nursuprianah, I. (2015). Pembelajaran Matematika di Madrasah Ibtidaiyah (MI). Akbar Kreatif Mandiri.

Sadiman, A. (2012). Media Pendidikan: Pengertian, Pengembangan dan Pemanfaatannya. Alfabeta, CV.
Salam, N., Safei, S., \& Jamilah, J. (2019). Pengembangan Media Pembelajaran. AL-Ahya, 01(01), 52-69.

Sugiyono. (2017). Metode Penelitian Kuantitatif, Kualitatif, dan $R \& D$. Alfabeta, CV.

Sundayana, R. (2016). Media dan Alat Peraga dalam Pembelajaran Matematika. Alfabeta. 